The final publication is available at Springer via http://dx.doi.org/10.1007/s12283-016-0200-3

1

\title{
Body Segment Parameters of Paralympic Athletes From Dual-Energy X-Ray Absorptiometry
}

Brock Laschowski ${ }^{1}$ and John McPhee ${ }^{1,2}$

${ }^{1}$ Department of Mechanical and Mechatronics Engineering, University of Waterloo, Canada ${ }^{2}$ Department of Systems Design Engineering, University of Waterloo, Canada

**Special Issue on Technology for Disability Sport**
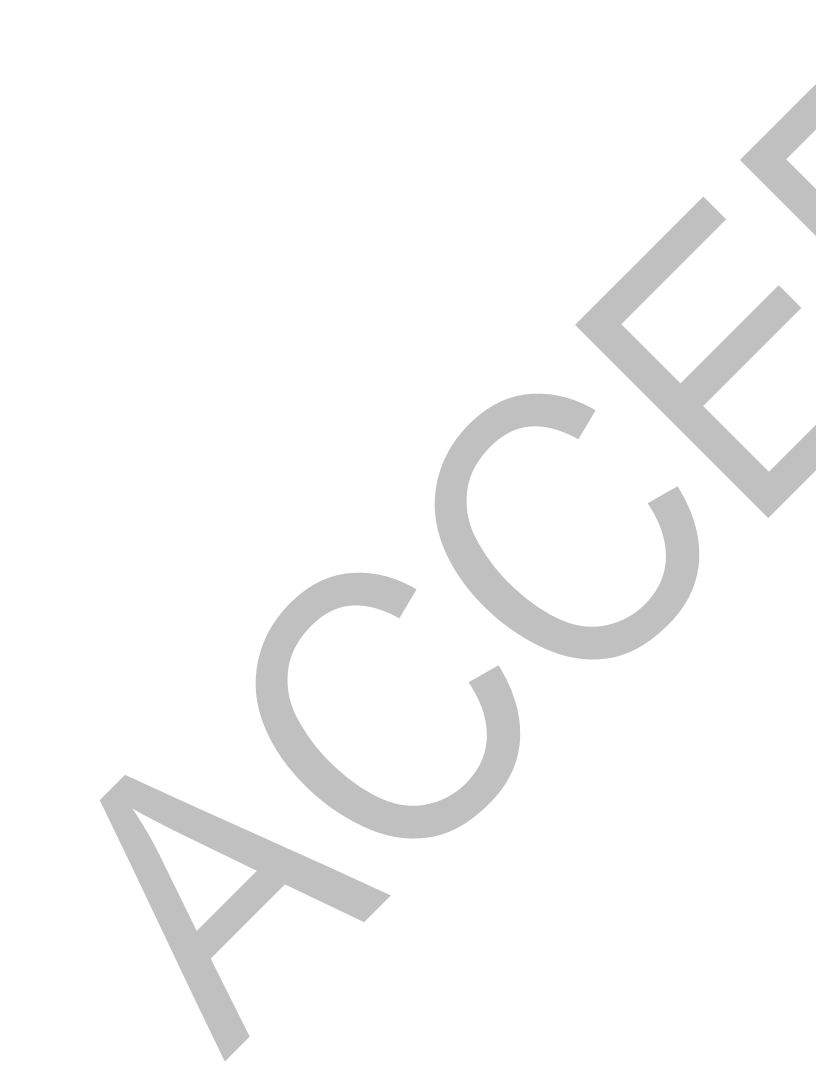

Funding: This research was funded by Dr. John McPhee's Tier I Canada Research Chair in Biomechatronic System Dynamics.

Conflict of Interest Disclosure: The authors declare that they have no conflict of interest. Correspondence Address: Brock Laschowski, Department of Mechanical and Mechatronics Engineering, University of Waterloo, Ontario N2L 3G1, Canada. Email: blaschow@uwaterloo.ca. Telephone: 519-884-4567 ext. 33825 


\section{Abstract}

38 This research represents the first documented investigation into the body segment parameters of

39 Paralympic athletes (e.g., individuals with spinal cord injuries and lower extremity amputations). Two-

40 dimensional body segment parameters (i.e., mass, length, position vector of the center of mass, and

41 principal mass moment of inertia about the center of mass) were quantified from dual-energy $\mathrm{x}$-ray

42 absorptiometry (DXA). In addition to establishing a body segment parameter database of Paralympic

43 athletes for prospective scientists and engineers, the mass of each body segment as experimentally

44 measured via the DXA imaging was compared with that reported by previous research of able-bodied

45 cadavers. In general, there were significant differences in the body segment masses between the

46 different methods. These findings support the implementation of the proposed database for designing

47 valid multibody biomechanical models of Paralympic athletes with distinct physical disabilities. 


\section{Introduction}

73 The effectiveness of biomechanical modelling (e.g., inverse and forward dynamics) is contingent upon

74 the extent to which the mechanical approximation of the human body accurately represents the 75 anatomical structure. The human body can be modelled as a multibody system whereby each body 76 segment can be characterized by specific mechanical parameters (e.g., mass, length, position vector of 77 the center of mass, and principal mass moment of inertia about the center of mass). The cadaveric research by Clauser et al [1] and Dempster [2] comprise two of the most renowned investigations for determining human body segment parameters. These investigations presented a number of anthropometric proportionalities for each body segment, including: i) the position vector of the center of mass as a proportion of the segment's length, ii) the segment's mass as a proportion of the subject's total body mass, and iii) the radius of gyration about the center of mass as a proportion of the segment's length. Clauser et al [1] and Dempster [2] focused on elderly able-bodied Caucasian males (i.e., Clauser et al [1]: $n=13$ cadavers, age $=49 \pm 13$ years, supine height $=1.727 \pm 0.059 \mathrm{~m}$, total body mass $=$ $66.52 \pm 8.70 \mathrm{~kg}$; Dempster [2]: $n=8$ cadavers, age $=69 \pm 11$ years, supine height $=1.694 \pm 0.112 \mathrm{~m}$, total body mass $=59.53 \pm 8.32 \mathrm{~kg}$ ).

Recent multibody biomechanical models of manual wheelchair users [3-6] (e.g., individuals with spinal cord injuries) have utilized the anthropometric proportionalities by Clauser et al [1] and Dempster [2] to represent the body segment parameters. Nevertheless, it has been well documented that manual wheelchair users have significantly less skeletal muscle mass [7-10], lower bone mineral content [7, 10], and more adipose tissue $[7,9-10]$ in the lower extremities than able-bodied matched controls. Several studies have also reported higher skeletal muscle mass in the upper extremities of manual wheelchair users compared with able-bodied equivalents [9]. Accordingly, the validity of using the anthropometric proportionalities by Clauser et al [1] and Dempster [2] to represent the body segment parameters of manual wheelchair users (particularly the mass parameter) is questionable.

Medical imaging modalities like computed tomography (CT) and magnetic resonance imaging (MRI) have been used to measure in vivo the body segment parameters of living subjects [10-11]. These modalities are time consuming and expensive, and involve large doses of ionizing radiation in the case of CT imaging (i.e., 10,000-15,000 $\mu$ Sv per total body scan) [10-11]. An emerging medical imaging modality is dual-energy $x$-ray absorptiometry (DXA). Compared with CT and MRI, DXA imaging is faster, more accessible, inexpensive, simple to operate, and involves minimal doses of radiation [10, 12-13]. Moreover, DXA imaging is not enclosed, which minimizes the likelihood of the subject feeling claustrophobic. Previous research has used DXA imaging to measure the body compositions of manual wheelchair users [9-10, 14-16]. Nevertheless, these investigations were limited to recreationally active individuals and/or did not include segmental analyses (i.e., only total body measurements were 
106

107

108

109

110

111

112

113

114

115

116

117

118

119

120

121

122

123

124

125

126

127

128

129

130

131

132

133

134

135

136

137

138

reported). To the best of the authors' knowledge, there has been no research published on the body segment parameters of Paralympic athletes. This deficiency in the literature has impeded valid multibody biomechanical modelling of this elite population. The following research experimentally measured the body segment parameters of Paralympic athletes using DXA imaging. The objective of this research was twofold: i) establish a body segment parameter database for prospective scientists and engineers interested in modelling Paralympic athletes, and ii) compare the mass of each body segment as measured via the DXA imaging with that reported by Clauser et al [1] and Dempster [2].

\section{Methods}

\subsection{Paralympic Athletes}

The sample included the entire Canadian Paralympic Wheelchair Curling Team $(n=6)$. Canada has won every gold medal in wheelchair curling at the Paralympic Games since its inauguration in 2006. A description of each Paralympian is provided in Table 1; the sample encompassed a variety of physical disabilities. For athletes with spinal cord injuries, motor impairments were characterized by the American Spinal Injury Association Impairment Scale. Informed written consent was obtained and the Canadian Sport Institute Ontario Research Ethics Board approved this research.

\subsection{Dual-Energy X-Ray Absorptiometry}

Total body DXA imaging was conducted at the Canadian Sport Institute Ontario using a Lunar iDXA (GE Healthcare Lunar, USA). DXA emits a "narrow angled" fan-beam x-ray filtered at two levels of energy: 41 and $74 \mathrm{keV}$ [17]. As the beam passes through the athlete's body, photons are attenuated via Compton scattering and photoelectric absorption, and the emerging energy levels are diminished [12]. Based on the beam's attenuation, percentages of adipose tissue, bone mineral content, and lean soft tissue (e.g., skeletal muscle) are determined on a pixel-by-pixel basis. Each pixel is $0.25 \times 0.30 \mathrm{~mm}$ [17].

Each Paralympian fasted for 12 hours (i.e., no food and fluids) and abstained from physical activity and calcium supplementation for 24 hours prior to the DXA imaging. The DXA instrumentation was calibrated against a criterion phantom block [17]. The athletes wore compression undergarments, removed all jewellery, and voided their bladders before the DXA imaging. Total body masses were measured using an electronic chair scale with a $\pm 0.1 \mathrm{~kg}$ tolerance (Model 952, SECA GmbH \& Co. KG., Germany). A medical radiation technologist laid each Paralympian supine in the anatomical position on the DXA table. Analogous with previous research [10], the athletes underwent two total body DXA scans and were repositioned between scans. Each scan took approximately 7 minutes to complete and had an effective dose of radiation of $0.96 \mu \mathrm{Sv}$ [17]. Data were analyzed with enCORE version 15 software (GE Medical Systems Ultrasound and Primary Care Diagnostics, LLC, USA). The DXA instrumentation 
reconstructs two-dimensional images in the frontal plane (Fig. 1). Each total body DXA image was manually delineated into fourteen segments: head-and-neck (H\&N), torso (TOR), and right and left upper arms (UA), forearms (FA), hands (HD), thighs (TH), shanks (SH), and feet (FT). Similar proximal and distal endpoints used by Clauser et al [1] and Dempster [2] were used to delineate each body segment in the total body DXA images.

\subsection{Cadaver Research}

The mass of each body segment as a proportion of the Paralympian's total body mass $\left(P_{m_{i}}\right)$ was calculated by

$P_{m_{i}}=\frac{m_{i}}{m_{\text {total }}}$

where $m_{i}$ is the mass of a given body segment and $m_{\text {total }}$ is the Paralympian's total body mass, both of which were experimentally measured via the DXA imaging. The $P_{m_{i}}$ were compared with the mass proportionalities $\left(P_{m_{i}}^{\prime}\right)$ reported by Clauser et al [1] and Dempster [2]. The cadaveric investigations [1-2] measured the mass of each body segment with gauges accurate to $0.001 \mathrm{~kg}$. The sums of the $P_{m_{i}}^{\prime}$ by Clauser et al [1] and Dempster [2] equate to 0.99 and 0.95, respectively. These undervaluations are attributed to fluid and tissue losses sustained during the cadaver dissections [1-2].

\section{Results}

The length of each body segment for each Paralympic athlete is shown in Table 2. The measurements are presented as arithmetic means across consecutive DXA scans with the uncertainties expressed as standard deviations. The lengths represent the linear distances between the proximal and distal endpoints. The measurements had a high degree of test-retest reliability, as indicated by the small standard deviations. For Paralympian's A1-A6, the lengths differed by $3.4 \% \pm 3.1$ percentage points (pp) between parallel body segments in the right and left extremities. Similar inter- and intra-subject asymmetrical differences have been previously reported for able-bodied individuals [1-2].

Table 3 presents the mass $\left(m_{i}\right)$ of each body segment for each Paralympic athlete as experimentally measured via the DXA imaging. For Paralympian's A1-A6, the $m_{i}$ differed by $5.4 \% \pm 4.6$ pp between corresponding body segments in the right and left extremities. Excluding the athlete with the unilateral transfemoral amputation (i.e., Paralympian A1), the largest asymmetrical difference in mass was measured between the thigh segments of Paralympian A5 (i.e., up to $20.2 \%$ ). This difference can be explained by the fact that Paralympian $\mathrm{A} 5$ has a titanium intramedullary implant in the right femur. Whenever the DXA beam is radiated against a metallic implant, insufficient amounts of data transmit through to the DXA receiver and the mass of that area cannot be quantified. The lower $m_{i}$ of the right 
171 thigh segment, relative to the left side, for Paralympian A5 can be attributed to the high photon

172 attenuation in the pixels coinciding with the femoral intramedullary implant.

173

174

175

176

177

178

179

180

181

182

183

184

185

186

187

188

189

190

191

192

193

194

195

196

197

198

199

200

201

202

203

The mass measurements had a high degree of test-retest reliability, as evidenced by the minor uncertainties. Summing the $m_{i}$ of each body segment for each Paralympic athlete resulted in total body masses: $A 1=80.253 \pm 0.104 \mathrm{~kg}, \mathrm{~A} 2=64.206 \pm 0.141 \mathrm{~kg}, \mathrm{~A} 3=116.232 \pm 0.303 \mathrm{~kg}, \mathrm{~A} 4=72.962 \pm$ $0.078 \mathrm{~kg}, \mathrm{~A} 5=87.208 \pm 0.955 \mathrm{~kg}$, and $\mathrm{A} 6=54.763 \pm 0.182 \mathrm{~kg}$. The electronic chair scale measured total body masses: $A 1=80.9 \pm 0.1 \mathrm{~kg}, \mathrm{~A} 2=64.6 \pm 0.1 \mathrm{~kg}, \mathrm{~A} 3=118.7 \pm 0.1 \mathrm{~kg}, \mathrm{~A} 4=71.1 \pm 0.1 \mathrm{~kg}$, $\mathrm{A} 5=81.2 \pm 0.1 \mathrm{~kg}$, and $\mathrm{A} 6=57.9 \pm 0.1 \mathrm{~kg}$. Some of the differences in total body mass between the DXA and chair scale measurements can be accredited to the DXA instrumentation omitting the masses of the pixels corresponding with metallic implants.

For Paralympian's A1-A6, the $P_{m_{i}}$ of each body segment as determined via the DXA imaging were compared with the $P_{m_{i}}^{\prime}$ reported by Clauser et al [1] and Dempster [2] (see Fig 2 and 3). The results are displayed as percent differences between the DXA and cadaveric measurements; the uncertainties represent inter-athlete differences. Negative quantities indicate that the $P_{m_{i}}^{\prime}$ were less than the $P_{m_{i}}$ and vice versa for positive quantities. Compared with the $P_{m_{i}}$ from the DXA imaging, the $P_{m_{i}}^{\prime}$ were $14.7 \% \pm$ $17.1 \mathrm{pp}$ lower for the upper extremity body segments (i.e., head-and-neck, torso, upper arms, and forearms) and $18.5 \% \pm 15.8 \mathrm{pp}$ higher for those in the lower extremities (i.e., thighs, shanks, and feet).

\section{Discussion and Conclusion}

The objective of this research was twofold: i) establish a body segment parameter database of Paralympic athletes with distinct physical disabilities, and ii) compare the mass of each body segment as experimentally measured via the DXA imaging with that reported by Clauser et al [1] and Dempster [2]. Compared with the DXA measurements, the mass proportionalities by the cadaveric investigations [1-2] were lower for the upper extremity body segments and higher for those in the lower extremities. This may be explained by the fact that manual wheelchair users characteristically have lower skeletal muscle mass $[7-10]$ and bone mineral content $[7,10]$ in the lower extremities and higher skeletal muscle mass in the upper extremities [9] compared with able-bodied matched controls. Previous research [18-20] has demonstrated that differences in body segment parameters (particularly the mass parameter) can significantly affect the resultant joint moments of force during inverse dynamics modelling. The measured differences between the DXA and cadaveric quantities support the implementation of the proposed database for designing valid multibody biomechanical models of Paralympic wheelchair curlers.

There is insufficient evidence to suggest that the position vector of the center of mass and the principal mass moment of inertia about the center of mass of a given body segment significantly differ 
204

205

206

207

208

209

210

211

212

213

214

215

216

217

218

219

220

221

222

223

224

225

226

227

228

229

230

231

232

233

234

between manual wheelchair users and able-bodied matched controls. Accordingly, the position vector of the center of mass from the proximal endpoint $\left(r_{C M_{i}}\right)$ and the principal mass moment of inertia about the center of mass $\left(I_{C M_{i}}\right)$ can be approximated via

$r_{C M_{i}}=P_{r_{C M_{i}}}^{\prime} L_{i}$

$I_{C M_{i}}=m_{i}\left(P_{k_{C M_{i}}}^{\prime} L_{i}\right)^{2}$

where $L_{i}$ is the segment's length as experimentally measured via the DXA imaging (see Table 2), $P_{r_{C M_{i}}^{\prime}}$ is the position vector of the center of mass from the proximal endpoint as a proportion of $L_{i}$, and $P_{k_{C M_{i}}}$ is the radius of gyration about the center of mass as a proportion of $L_{i}$. The latter two terms were obtained from Clauser et al [1]. Efforts are presently underway to measure the $r_{C M_{i}}$ and the $I_{C M_{i}}$ of each body segment using customized digital image processing algorithms. The $r_{C M_{i}}$ and the proximal and distal endpoints were assumed to be located along the segment's midline in the medial-lateral axis. The $r_{C M_{i}}$ and the $I_{C M_{i}}$ were determined in the frontal plane (Tables 4 and 5). These body segment parameters, coupled with the mass and length measurements, can be used to biomechanically model Paralympic wheelchair curlers with distinct physical disabilities.

Though limited to total body measurements, previous research has investigated Paralympic wheelchair curlers [21]. The total body compositions of ten Italian Paralympic wheelchair curlers (i.e., age $=42 \pm 9$ years, total body mass $=82.30 \pm 29.29 \mathrm{~kg}$ ) were assessed using skinfold caliper measurements. Skinfold calipers measure the girth of subcutaneous adipose tissue. Several equations have been proposed in the literature, which estimate the total body fat mass percentage using skinfold caliper measurements. Bernardi et al [21] calculated a mean total body fat mass percentage of $26.2 \% \pm$ $7.7 \mathrm{pp}$ for the Italian Paralympic athletes; the sample included individuals with spinal cord injuries and lower extremity amputations. These total body fat mass percentages were lower than those measured in this research (i.e., $\mathrm{A} 1=33.7 \% \pm 0.2 \mathrm{pp}, \mathrm{A} 2=39.6 \% \pm 0.1 \mathrm{pp}, \mathrm{A} 3=30.7 \% \pm 0.1 \mathrm{pp}, \mathrm{A} 4=50.7 \% \pm$ $0.3 \mathrm{pp}, \mathrm{A} 5=34.6 \% \pm 0.6 \mathrm{pp}$, and $\mathrm{A} 6=27.8 \% \pm 0.3 \mathrm{pp}$ ). Bernardi et al [21] suggested that Paralympic wheelchair curlers might actually benefit from higher total body fat mass insofar as the additional mass moment of inertia about the vertical axis could increase the athlete's "postural stability" while delivering the curling stone.

Previous research has demonstrated the validity of using DXA imaging to quantify the body segment parameters of able-bodied individuals [12-13]. Nevertheless, particular consideration is needed for Paralympic athletes due to the presence of metallic implants. Whenever the DXA beam is radiated against a metallic implant (e.g., stainless steel or titanium), the photons are attenuated via Compton 
235 scattering and photoelectric absorption, and insufficient amounts of data transmit through to the DXA 236 receiver. Consequently, the mass of that area cannot be computed. The effects of these omissions were 237 evident when analyzing the masses of parallel body segments between the left and right extremities in 238 athletes with unilateral implants (i.e., Paralympian A5). Future research should consider developing 239 model-based and/or experimental techniques to compensate for the DXA instrumentation omitting the masses of the pixels coinciding with metallic implants. 


\section{References}

242 1. Clauser CE, McConville JT, Young JW (1969) Weight, volume and center of mass of segments of the 243 human body. Aerospace Medical Research Laboratory Technical Report 60-70. Wright Patterson Air Force 244 Base, USA.

245 2. Dempster WT (1955) Space requirements of the seated operator: geometrical, kinematic, and 246 mechanical aspects of the body with special reference to the limbs. Wright Air Development Center 247 Technical Report 55-159. Wright-Patterson Air Force Base, USA.

248

249

250

251

3. Morrow MM, Rankin JW, Neptune RR, Kaufman KR (2014) A comparison of static and dynamic optimization muscle force predictions during wheelchair propulsion. Journal of Biomechanics 47: 34593465.

4. Morrow MM, Hurd WJ, Kaufman KR, An KN (2010) Shoulder demands in manual wheelchair users across a spectrum of activities. Journal of Electromyography and Kinesiology 20: 61-67.

5. Rankin JW, Kwarciak AM, Richter WM, Neptune RR (2012) The influence of wheelchair propulsion technique on upper extremity muscle demand: A simulation study. Clinical Biomechanics 27: 879-886.

6. Slowik SJ, Neptune RR (2013) A theoretical analysis of the influence of wheelchair seat position on upper extremity demand. Clinical Biomechanics 28: 378-385.

7. Kocina P (1997) Body composition of spinal cord injured adults. Sports Medicine 23: 48-60.

8. Lussier L, Knight J, Bell G, Lohman T, Morris AF (1983) Body composition comparison in two elite female wheelchair athletes. Paraplegia 21: 16-22.

9. Sutton L, Wallace J, Goosey-Tolfrey V, Scott M, Reilly T (2009) Body composition of female wheelchair athletes. International Journal of Sports Medicine 30: 259-265.

10. Keil M, Totosy de Zepetnek JO, Brooke-Wavell K, Goosey-Tolfrey VL (2016) Measurement precision of body composition variables in elite wheelchair athletes, using dual-energy X-ray absorptiometry.

European Journal of Sport Science 16: 65-71.

11. Pearsall DJ, Reid JG (1994) The study of human body segment parameters in biomechanics. Sports Medicine 18: 126-140.

12. Durkin JL, Dowling JJ, Andrews DM (2002) The measurement of body segment inertial parameters using dual energy x-ray absorptiometry. Journal of Biomechanics 35: 1575-1580. 
269 13. Durkin JL, Dowling JJ (2003) Analysis of body segment parameter differences between four human

270 populations and the estimation errors of four popular mathematical models. Journal of Biomechanical

271 Engineering 125: 515-522.

272 14. Goktepe AS, Yilmaz B, Alaca R, Yazicioglu K, Mohur H, Gunduz S (2004) Bone density loss after spinal

273 cord injury: elite paraplegic basketball players vs. paraplegic sedentary persons. American Journal of

274 Physical Medicine and Rehabilitation 83: 279-283.

275 15. Inukai Y, Takahashi K, Wang DH, Kira S (2006) Assessment of total and segmental body composition

276 in spinal cord-injured athletes in Okayama prefecture of Japan. Acta Medica Okayama 60: 99-106.

277 16. Mojtahedi MC, Valentine RJ, Evans EM (2009) Body composition assessment in athletes with spinal

278 cord injury: comparison of field methods with dual-energy x-ray absorptiometry. Spinal Cord 47: 698-704.

279 17. GE Healthcare Lunar (2013) enCORE-based X-ray Bone Densitometer: User Manual. Wisconsin, USA.

280 18. Andrews JG, Mish SP (1996) Methods for investigating the sensitivity of joint resultants to body

281 segment parameter variations. Journal of Biomechanics 29: 651-654.

282 19. Kingma I, Toussaint HM, De Looze MP, Van Dieen JH (1996) Segment inertial parameter evaluation in 283 two anthropometric models by application of a dynamic linked segment model. Journal of Biomechanics 284 29: 693-704.

285 20. Rao G, Amarantini D, Berton E, Favier D (2006) Influence of body segments' parameters estimation 286 models on inverse dynamics solutions during gait. Journal of Biomechanics 39: 1531-1536.

287 21. Bernardi M, Carucci S, Faiola F, Egidi F, Marini C, Castellano V, Faina M (2012) Physical fitness 288 evaluation of Paralympic winter sports sitting athletes. Clinical Journal of Sports Medicine 22: 26-30. 
Table 1. The physical disability of each Paralympic athlete. Athletes were identified via codes (i.e., $A 1$ to A6). For athletes with spinal cord injuries (SCI), motor impairments were characterized by the American Spinal Injury Association (ASIA) Impairment Scale.

Code Physical Disability

Metallic Implant

ASIA

A1 Unilateral Transfemoral Amputation

N/A

$\mathrm{N} / \mathrm{A}$

A2 Incomplete SCI Between $12^{\text {th }}$ Thoracic and $1^{\text {st }}$ Lumbosacral Vertebrae

A3 Bilateral Total Knee Replacements

A4 Complete SCI Between $11^{\text {th }}$ and $12^{\text {th }}$ Thoracic Vertebrae

A5 Incomplete SCI Between $5^{\text {th }}$ and $6^{\text {th }}$ Cervical Vertebrae

Stainless Steel Harrington Implants

C

Type 2 Titanium Implants

$\mathrm{N} / \mathrm{A}$

N/A

A

Titanium Intramedullary Implant

C

Stainless Steel Harrington Implants A and Intrathecal Baclofen Pump 
294

295

296
Table 2. The length $(\mathrm{m})$ of each body segment for each Paralympic athlete. The measurements are presented as arithmetic means \pm standard deviations across consecutive DXA scans. Segments in the extremities are subcategorized into right and left sides.

\begin{tabular}{|c|c|c|c|c|c|c|}
\hline Segment & $\mathrm{A} 1$ & $\mathrm{~A} 2$ & A3 & A4 & A5 & A6 \\
\hline $\mathrm{H} \& \mathrm{~N}$ & $\begin{array}{l}0.250 \pm \\
0.009\end{array}$ & $\begin{array}{l}0.249 \pm \\
0.001\end{array}$ & $\begin{array}{l}0.274 \pm \\
0.003\end{array}$ & $\begin{array}{l}0.265 \pm \\
0.001\end{array}$ & $\begin{array}{l}0.265 \pm \\
0.005\end{array}$ & $\begin{array}{l}0.304 \pm \\
0.005\end{array}$ \\
\hline TOR & $\begin{array}{l}0.599 \pm \\
0.015\end{array}$ & $\begin{array}{l}0.563 \pm \\
0.002\end{array}$ & $\begin{array}{l}0.649 \pm \\
0.002\end{array}$ & $\begin{array}{l}0.567 \pm \\
0.001\end{array}$ & $\begin{array}{l}0.588 \pm \\
0.008\end{array}$ & $\begin{array}{l}0.525 \pm \\
0.022\end{array}$ \\
\hline UAR & $\begin{array}{l}0.283 \pm \\
0.001\end{array}$ & $\begin{array}{l}0.256 \pm \\
0.007\end{array}$ & $\begin{array}{l}0.311 \pm \\
0.020\end{array}$ & $\begin{array}{l}0.280 \pm \\
0.004\end{array}$ & $\begin{array}{l}0.291 \pm \\
0.005\end{array}$ & $\begin{array}{l}0.298 \pm \\
0.001\end{array}$ \\
\hline UAL & $\begin{array}{l}0.284 \pm \\
0.009\end{array}$ & $\begin{array}{l}0.255 \pm \\
0.012\end{array}$ & $\begin{array}{l}0.320 \pm \\
0.002\end{array}$ & $\begin{array}{l}0.275 \pm \\
0.001\end{array}$ & & $\begin{array}{l}0.304 \pm \\
0.001\end{array}$ \\
\hline FAR & $\begin{array}{l}0.236 \pm \\
0.003\end{array}$ & $\begin{array}{l}0.222 \pm \\
0.001\end{array}$ & $\begin{array}{l}0.271 \pm \\
0.010\end{array}$ & $\begin{array}{l}0.226 \pm \\
0.001\end{array}$ & $\begin{array}{l}0.276 \pm \\
0.002\end{array}$ & $\begin{array}{l}0.273 \pm \\
0.002\end{array}$ \\
\hline FAL & $\begin{array}{l}0.228 \pm \\
0.002\end{array}$ & $\begin{array}{l}0.224 \pm \\
0.001\end{array}$ & $\begin{array}{l}0.267 \pm \\
0.004\end{array}$ & $\begin{array}{l}0.216 \pm \\
0.001\end{array}$ & $\begin{array}{l}0.280 \pm \\
0.007\end{array}$ & $\begin{array}{l}0.260 \pm \\
0.001\end{array}$ \\
\hline HDR & $\begin{array}{l}0.156 \pm \\
0.007\end{array}$ & $\begin{array}{l}0.165 \pm \\
0.001\end{array}$ & $\begin{array}{l}0.192 \pm \\
0.012\end{array}$ & $\begin{array}{l}0.165 \pm \\
0.002\end{array}$ & $\begin{array}{l}0.123 \pm \\
0.001\end{array}$ & $\begin{array}{l}0.178 \pm \\
0.009\end{array}$ \\
\hline $\mathrm{HDL}$ & $\begin{array}{l}0.145 \pm \\
0.020\end{array}$ & $\begin{array}{l}0.170 \pm \\
0.004\end{array}$ & $\begin{array}{l}0.182 \pm \\
0.007\end{array}$ & $\begin{array}{l}0.169 \pm \\
0.003\end{array}$ & $\begin{array}{l}0.117 \pm \\
0.002\end{array}$ & $\begin{array}{l}0.180 \pm \\
0.006\end{array}$ \\
\hline THR & $\begin{array}{l}0.397 \pm \\
0.011\end{array}$ & $\begin{array}{l}0.372 \pm \\
0.017\end{array}$ & $\begin{array}{l}0.406 \pm \\
0.010\end{array}$ & $\begin{array}{l}0.369 \pm \\
0.001\end{array}$ & $\begin{array}{l}0.469 \pm \\
0.003\end{array}$ & $\begin{array}{l}0.413 \pm \\
0.007\end{array}$ \\
\hline THL & $\begin{array}{l}0.250 \pm \\
0.011\end{array}$ & $\begin{array}{l}0.379 \pm \\
0.008\end{array}$ & $\begin{array}{l}0.411 \pm \\
0.001\end{array}$ & $\begin{array}{l}0.362 \pm \\
0.001\end{array}$ & $\begin{array}{l}0.464 \pm \\
0.004\end{array}$ & $\begin{array}{l}0.459 \pm \\
0.001\end{array}$ \\
\hline SHR & $\begin{array}{l}0.339 \pm \\
0.004\end{array}$ & $\begin{array}{l}0.335 \pm \\
0.001\end{array}$ & $\begin{array}{l}0.424 \pm \\
0.004\end{array}$ & $\begin{array}{l}0.337 \pm \\
0.003\end{array}$ & $\begin{array}{l}0.398 \pm \\
0.001\end{array}$ & $\begin{array}{l}0.373 \pm \\
0.008\end{array}$ \\
\hline SHL & $N / A \pm N /$ & $\begin{array}{l}0.332 \pm \\
0.001\end{array}$ & $\begin{array}{l}0.423 \pm \\
0.014\end{array}$ & $\begin{array}{l}0.346 \pm \\
0.005\end{array}$ & $\begin{array}{l}0.400 \pm \\
0.001\end{array}$ & $\begin{array}{l}0.409 \pm \\
0.003\end{array}$ \\
\hline FTR & $\begin{array}{l}0.187 \pm \\
0.001\end{array}$ & $\begin{array}{l}0.164 \pm \\
0.003\end{array}$ & $\begin{array}{l}0.174 \pm \\
0.019\end{array}$ & $\begin{array}{l}0.156 \pm \\
0.008\end{array}$ & $\begin{array}{l}0.178 \pm \\
0.003\end{array}$ & $\begin{array}{l}0.193 \pm \\
0.002\end{array}$ \\
\hline FTL & $\mathrm{N} / \mathrm{A} \pm \mathrm{N} / \mathrm{A}$ & $\begin{array}{l}0.157 \pm \\
0.001\end{array}$ & $\begin{array}{l}0.161 \pm \\
0.009\end{array}$ & $\begin{array}{l}0.155 \pm \\
0.005\end{array}$ & $\begin{array}{l}0.187 \pm \\
0.003\end{array}$ & $\begin{array}{l}0.193 \pm \\
0.001\end{array}$ \\
\hline
\end{tabular}


Table 3. The mass $(\mathrm{kg})$ of each body segment (i.e., summation of the bone mineral content, adipose tissue, and skeletal muscle) for each Paralympic athlete. The quantities are arithmetic means \pm standard deviations across consecutive DXA scans. Segments in the extremities are subcategorized into right and left sides.

\begin{tabular}{|c|c|c|c|c|c|c|}
\hline Segment & $\mathrm{A} 1$ & $\mathrm{~A} 2$ & A3 & A4 & A5 & A6 \\
\hline $\mathrm{H} \& \mathrm{~N}$ & $\begin{array}{l}6.361 \pm \\
0.248\end{array}$ & $\begin{array}{l}5.990 \pm \\
0.062\end{array}$ & $\begin{array}{l}8.425 \pm \\
0.295\end{array}$ & $\begin{array}{l}6.137 \pm \\
0.010\end{array}$ & $\begin{array}{l}6.967 \pm \\
0.085\end{array}$ & $\begin{array}{l}6.496 \pm \\
0.127\end{array}$ \\
\hline TOR & $\begin{array}{l}46.50 \pm \\
0.011\end{array}$ & $\begin{array}{l}34.79 \pm \\
0.185\end{array}$ & $\begin{array}{l}65.54 \pm \\
1.188\end{array}$ & $\begin{array}{l}37.16 \pm \\
0.235\end{array}$ & $\begin{array}{l}44.62 \pm \\
0.677\end{array}$ & $\begin{array}{l}24.57 \pm \\
0.445\end{array}$ \\
\hline UAR & $\begin{array}{l}3.521 \pm \\
0.173\end{array}$ & $\begin{array}{l}2.533 \pm \\
0.017\end{array}$ & $\begin{array}{l}3.799 \pm \\
0.381\end{array}$ & $\begin{array}{l}3.319 \pm \\
0.012\end{array}$ & $\begin{array}{l}3.099 \pm \\
0.192\end{array}$ & $\begin{array}{l}2.431 \pm \\
0.035\end{array}$ \\
\hline UAL & $\begin{array}{l}3.494 \pm \\
0.250\end{array}$ & $\begin{array}{l}2.480 \pm \\
0.083\end{array}$ & $\begin{array}{l}3.832 \pm \\
0.525\end{array}$ & $\begin{array}{l}2.887 \pm \\
0.173\end{array}$ & $\begin{array}{l}3.100 \pm \\
0.035\end{array}$ & $\begin{array}{l}2.357 \pm \\
0.087\end{array}$ \\
\hline FAR & $\begin{array}{l}1.395 \pm \\
0.023\end{array}$ & $\begin{array}{l}1.135 \pm \\
0.016\end{array}$ & $\begin{array}{l}1.721 \pm \\
0.074\end{array}$ & $\begin{array}{l}1.057 \pm \\
0.025\end{array}$ & $\begin{array}{l}1.371 \pm \\
0.009\end{array}$ & $\begin{array}{l}1.104 \pm \\
0.007\end{array}$ \\
\hline FAL & $\begin{array}{l}1.338 \pm \\
0.028\end{array}$ & $\begin{array}{l}1.173 \pm \\
0.018\end{array}$ & $\begin{array}{l}1.560 \pm \\
0.064\end{array}$ & $\begin{array}{l}0.995 \pm \\
0.005\end{array}$ & $\begin{array}{l}1.302 \pm \\
0.027\end{array}$ & $\begin{array}{l}1.042 \pm \\
0.005\end{array}$ \\
\hline HDR & $\begin{array}{l}0.496 \pm \\
0.008\end{array}$ & $\begin{array}{l}0.419 \pm \\
0.001\end{array}$ & $\begin{array}{l}0.598 \pm \\
0.013\end{array}$ & $\begin{array}{l}0.322 \pm \\
0.003\end{array}$ & $\begin{array}{l}0.396 \pm \\
0.011\end{array}$ & $\begin{array}{l}0.370 \pm \\
0.021\end{array}$ \\
\hline $\mathrm{HDL}$ & $\begin{array}{l}0.509 \pm \\
0.008\end{array}$ & $\begin{array}{l}0.422 \pm \\
0.006\end{array}$ & $\begin{array}{l}0.617 \pm \\
0.004\end{array}$ & $\begin{array}{l}0.323 \pm \\
0.001\end{array}$ & $\begin{array}{l}0.437 \pm \\
0.013\end{array}$ & $\begin{array}{l}0.375 \pm \\
0.032\end{array}$ \\
\hline THR & $\begin{array}{l}8.090 \pm \\
0.144\end{array}$ & $\begin{array}{l}4.663 \pm \\
0.062\end{array}$ & $\begin{array}{l}9.326 \pm \\
0.187\end{array}$ & $\begin{array}{l}6.456 \pm \\
0.097\end{array}$ & $\begin{array}{l}8.383 \pm \\
0.629\end{array}$ & $\begin{array}{l}4.609 \pm \\
0.247\end{array}$ \\
\hline THL & $\begin{array}{l}4.047 \pm \\
0.030\end{array}$ & $\begin{array}{l}4.968 \pm \\
0.069\end{array}$ & $\begin{array}{l}9.526 \pm \\
0.387\end{array}$ & $\begin{array}{l}7.093 \pm \\
0.074\end{array}$ & $\begin{array}{l}9.396 \pm \\
0.201\end{array}$ & $\begin{array}{l}4.938 \pm \\
0.078\end{array}$ \\
\hline SHR & $\begin{array}{l}3.408 \pm \\
0.057\end{array}$ & $\begin{array}{l}2.011 \pm \\
0.006\end{array}$ & $\begin{array}{l}4.525 \pm \\
0.073\end{array}$ & $\begin{array}{l}2.852 \pm \\
0.091\end{array}$ & $\begin{array}{l}3.482 \pm \\
0.034\end{array}$ & $\begin{array}{l}2.393 \pm \\
0.003\end{array}$ \\
\hline SHL & $\mathrm{N} / \mathrm{A} \pm \mathrm{N} / \mathrm{A}$ & $\begin{array}{l}2.033 \pm \\
0.004\end{array}$ & $\begin{array}{l}4.160 \pm \\
0.081\end{array}$ & $\begin{array}{l}2.821 \pm \\
0.098\end{array}$ & $\begin{array}{l}3.261 \pm \\
0.071\end{array}$ & $\begin{array}{l}2.336 \pm \\
0.016\end{array}$ \\
\hline FTR & $\begin{array}{l}1.097 \pm \\
0.013\end{array}$ & $\begin{array}{l}0.798 \pm \\
0.009\end{array}$ & $\begin{array}{l}1.313 \pm \\
0.070\end{array}$ & $\begin{array}{l}0.795 \pm \\
0.017\end{array}$ & $\begin{array}{l}1.039 \pm \\
0.008\end{array}$ & $\begin{array}{l}0.934 \pm \\
0.015\end{array}$ \\
\hline FTL & $\mathrm{N} / \mathrm{A} \pm \mathrm{N} / \mathrm{A}$ & $\begin{array}{l}0.790 \pm \\
0.012\end{array}$ & $\begin{array}{l}1.292 \pm \\
0.026\end{array}$ & $\begin{array}{l}0.745 \pm \\
0.044\end{array}$ & $\begin{array}{l}1.037 \pm \\
0.039\end{array}$ & $\begin{array}{l}0.944 \pm \\
0.011\end{array}$ \\
\hline
\end{tabular}


Table 4. The position vector of the center of mass $(\mathrm{m})$ of each body segment for each Paralympic athlete as computed via equation (2). The quantities are arithmetic means \pm standard deviations across consecutive DXA scans. The inter-scan uncertainties stem from the multiple length measurements $(L i)$. Segments in the extremities are subcategorized into right and left sides.

\begin{tabular}{|c|c|c|c|c|c|c|}
\hline Segment & $\mathrm{A} 1$ & $\mathrm{~A} 2$ & A3 & A4 & A5 & A6 \\
\hline $\mathrm{H} \& \mathrm{~N}$ & $\begin{array}{l}0.116 \pm \\
0.004\end{array}$ & $\begin{array}{l}0.116 \pm \\
0.004\end{array}$ & $\begin{array}{l}0.127 \pm \\
0.001\end{array}$ & $\begin{array}{l}0.123 \pm \\
0.001\end{array}$ & $\begin{array}{l}0.123 \pm \\
0.003\end{array}$ & $\begin{array}{l}0.141 \pm \\
0.002\end{array}$ \\
\hline TOR & $\begin{array}{l}0.228 \pm \\
0.006\end{array}$ & $\begin{array}{l}0.214 \pm \\
0.007\end{array}$ & $\begin{array}{l}0.247 \pm \\
0.001\end{array}$ & $\begin{array}{l}0.216 \pm \\
0.001\end{array}$ & $\begin{array}{l}0.224 \pm \\
0.003\end{array}$ & $\begin{array}{l}0.200 \pm \\
0.008\end{array}$ \\
\hline UAR & $\begin{array}{l}0.145 \pm \\
0.001\end{array}$ & $\begin{array}{l}0.131 \pm \\
0.004\end{array}$ & $\begin{array}{l}0.159 \pm \\
0.010\end{array}$ & $\begin{array}{l}0.143 \\
0.002\end{array}$ & $\begin{array}{l}0.149 \pm \\
0.002\end{array}$ & $\begin{array}{l}0.153 \pm \\
0.001\end{array}$ \\
\hline UAL & $\begin{array}{l}0.145 \pm \\
0.004\end{array}$ & $\begin{array}{l}0.131 \pm \\
0.006\end{array}$ & $\begin{array}{l}0.164 \pm \\
0.001\end{array}$ & $\begin{array}{l}0.141 \pm \\
0.001\end{array}$ & $\begin{array}{l}0.149 \pm \\
0.001\end{array}$ & $\begin{array}{l}0.156 \pm \\
0.001\end{array}$ \\
\hline FAR & $\begin{array}{l}0.092 \pm \\
0.001\end{array}$ & $\begin{array}{l}0.086 \pm \\
0.001\end{array}$ & $\begin{array}{l}0.105 \pm \\
0.004\end{array}$ & $\begin{array}{l}0.088 \pm \\
0.001\end{array}$ & $\begin{array}{l}0.108 \pm \\
0.001\end{array}$ & $\begin{array}{l}0.106 \pm \\
0.002\end{array}$ \\
\hline FAL & $\begin{array}{l}0.089 \pm \\
0.001\end{array}$ & $\begin{array}{l}0.087 \pm \\
0.004\end{array}$ & $\begin{array}{l}0.104 \pm \\
0.002\end{array}$ & $\begin{array}{l}0.084 \pm \\
0.001\end{array}$ & $\begin{array}{l}0.109 \pm \\
0.003\end{array}$ & $\begin{array}{l}0.101 \pm \\
0.001\end{array}$ \\
\hline HDR & $\begin{array}{l}0.028 \pm \\
0.001\end{array}$ & $\begin{array}{l}0.030 \pm \\
0.001\end{array}$ & $\begin{array}{l}0.035 \pm \\
0.002\end{array}$ & $\begin{array}{l}0.030 \pm \\
0.001\end{array}$ & $\begin{array}{l}0.022 \pm \\
0.001\end{array}$ & $\begin{array}{l}0.032 \pm \\
0.002\end{array}$ \\
\hline $\mathrm{HDL}$ & $\begin{array}{l}0.026 \pm \\
0.004\end{array}$ & $\begin{array}{l}0.031 \pm \\
0.001\end{array}$ & $\begin{array}{l}0.033 \pm \\
0.001\end{array}$ & $\begin{array}{l}0.031 \pm \\
0.001\end{array}$ & $\begin{array}{l}0.021 \pm \\
0.001\end{array}$ & $\begin{array}{l}0.032 \pm \\
0.001\end{array}$ \\
\hline THR & $\begin{array}{l}0.148 \pm \\
0.004\end{array}$ & $\begin{array}{l}0.139 \pm \\
0.006\end{array}$ & $\begin{array}{l}0.151 \pm \\
0.004\end{array}$ & $\begin{array}{l}0.137 \pm \\
0.001\end{array}$ & $\begin{array}{l}0.174 \pm \\
0.001\end{array}$ & $\begin{array}{l}0.154 \pm \\
0.002\end{array}$ \\
\hline THL & $N / A \pm N / A$ & $\begin{array}{l}0.141 \\
0.003\end{array}$ & $\begin{array}{l}0.153 \pm \\
0.001\end{array}$ & $\begin{array}{l}0.135 \pm \\
0.001\end{array}$ & $\begin{array}{l}0.173 \pm \\
0.002\end{array}$ & $\begin{array}{l}0.171 \pm \\
0.001\end{array}$ \\
\hline SHR & $\begin{array}{l}0.126 \\
0.001\end{array}$ & $\begin{array}{l}0.124 \pm \\
0.002\end{array}$ & $\begin{array}{l}0.157 \pm \\
0.002\end{array}$ & $\begin{array}{l}0.125 \pm \\
0.002\end{array}$ & $\begin{array}{l}0.147 \pm \\
0.001\end{array}$ & $\begin{array}{l}0.138 \pm \\
0.003\end{array}$ \\
\hline SHL & $N / A \pm N / A$ & $\begin{array}{l}0.123 \pm \\
0.004\end{array}$ & $\begin{array}{l}0.157 \pm \\
0.005\end{array}$ & $\begin{array}{l}0.128 \pm \\
0.003\end{array}$ & $\begin{array}{l}0.148 \pm \\
0.001\end{array}$ & $\begin{array}{l}0.152 \pm \\
0.001\end{array}$ \\
\hline FTR & $\begin{array}{l}0.084 \pm \\
0.001\end{array}$ & $\begin{array}{l}0.074 \pm \\
0.002\end{array}$ & $\begin{array}{l}0.078 \pm \\
0.008\end{array}$ & $\begin{array}{l}0.070 \pm \\
0.004\end{array}$ & $\begin{array}{l}0.082 \pm \\
0.002\end{array}$ & $\begin{array}{l}0.086 \pm \\
0.001\end{array}$ \\
\hline FTL & $N / A \pm N / A$ & $\begin{array}{l}0.070 \pm \\
0.001\end{array}$ & $\begin{array}{l}0.072 \pm \\
0.004\end{array}$ & $\begin{array}{l}0.069 \pm \\
0.002\end{array}$ & $\begin{array}{l}0.087 \pm \\
0.002\end{array}$ & $\begin{array}{l}0.087 \pm \\
0.001\end{array}$ \\
\hline
\end{tabular}


310

311

312

313

314

Table 5. The principal mass moment of inertia $\left(\mathrm{kg} \cdot \mathrm{m}^{2}\right)$ about the center of mass of each body segment for each Paralympic athlete as calculated via equation (3). The quantities are arithmetic means \pm standard deviations across consecutive DXA scans. The inter-scan uncertainties originate from the multiple length $\left(L_{i}\right)$ and mass $\left(m_{i}\right)$ measurements. Segments in the extremities are subcategorized into right and left sides.

\begin{tabular}{|c|c|c|c|c|c|c|}
\hline Segment & $\mathrm{A} 1$ & $\mathrm{~A} 2$ & $\mathrm{~A} 3$ & A4 & A5 & A6 \\
\hline $\mathrm{H} \& \mathrm{~N}$ & $\begin{array}{l}0.159 \pm \\
0.018\end{array}$ & $\begin{array}{l}0.149 \pm \\
0.003\end{array}$ & $\begin{array}{l}0.253 \pm \\
0.015\end{array}$ & $\begin{array}{l}0.172 \pm \\
0.001\end{array}$ & $\begin{array}{l}0.196 \pm \\
0.010\end{array}$ & $\begin{array}{l}0.240 \pm \\
0.013\end{array}$ \\
\hline TOR & $\begin{array}{l}3.087 \pm \\
0.152\end{array}$ & $\begin{array}{l}2.040 \pm \\
0.002\end{array}$ & $\begin{array}{l}5.102 \pm \\
0.129\end{array}$ & $\begin{array}{l}2.208 \pm \\
0.012\end{array}$ & & $\begin{array}{l}1.251 \pm \\
0.082\end{array}$ \\
\hline UAR & $\begin{array}{l}0.026 \pm \\
0.001\end{array}$ & $\begin{array}{l}0.015 \pm \\
0.001\end{array}$ & $\begin{array}{l}0.034 \pm \\
0.008\end{array}$ & $\begin{array}{l}0.024 \pm \\
0.001\end{array}$ & $\begin{array}{l}0.024 \pm \\
0.002\end{array}$ & $\begin{array}{l}0.020 \pm \\
0.001\end{array}$ \\
\hline UAL & $\begin{array}{l}0.026 \pm \\
0.003\end{array}$ & $\begin{array}{l}0.015 \pm \\
0.002\end{array}$ & $\begin{array}{l}0.036 \pm \\
0.004\end{array}$ & $\begin{array}{l}0.020 \pm \\
0.001\end{array}$ & $\begin{array}{l}0.024 \pm \\
0.001\end{array}$ & $\begin{array}{l}0.020 \pm \\
0.001\end{array}$ \\
\hline FAR & $\begin{array}{l}0.008 \pm \\
0.001\end{array}$ & $\begin{array}{l}0.006 \pm \\
0.001\end{array}$ & $\begin{array}{l}0.013 \\
0.001\end{array}$ & $\begin{array}{l}0.005 \pm \\
0.001\end{array}$ & $\begin{array}{l}0.012 \pm \\
0.001\end{array}$ & $\begin{array}{l}0.008 \pm \\
0.001\end{array}$ \\
\hline FAL & $\begin{array}{l}0.007 \pm \\
0.001\end{array}$ & $\begin{array}{l}0.006 \pm \\
0.001\end{array}$ & $\begin{array}{l}0.011 \\
0.001\end{array}$ & $\begin{array}{l}0.005 \pm \\
0.001\end{array}$ & $\begin{array}{l}0.010 \pm \\
0.001\end{array}$ & $\begin{array}{l}0.007 \pm \\
0.001\end{array}$ \\
\hline HDR & $\begin{array}{l}0.004 \pm \\
0.001\end{array}$ & $\begin{array}{l}0.004 \pm \\
0.001\end{array}$ & $\begin{array}{l}0.008 \pm \\
0.001\end{array}$ & $\begin{array}{l}0.003 \pm \\
0.001\end{array}$ & $\begin{array}{l}0.002 \pm \\
0.001\end{array}$ & $\begin{array}{l}0.004 \pm \\
0.001\end{array}$ \\
\hline HDL & $\begin{array}{l}0.004 \pm \\
0.002\end{array}$ & $\begin{array}{l}0.004 \pm \\
0.002\end{array}$ & $\begin{array}{l}0.007 \pm \\
0.001\end{array}$ & $\begin{array}{l}0.003 \pm \\
0.001\end{array}$ & $\begin{array}{l}0.002 \pm \\
0.001\end{array}$ & $\begin{array}{l}0.004 \pm \\
0.001\end{array}$ \\
\hline THR & $\begin{array}{l}0.154 \pm \\
0.012\end{array}$ & $\begin{array}{l}0.078 \pm \\
0.008\end{array}$ & $\begin{array}{l}0.186 \pm \\
0.005\end{array}$ & $\begin{array}{l}0.106 \pm \\
0.002\end{array}$ & $\begin{array}{l}0.223 \pm \\
0.014\end{array}$ & $\begin{array}{l}0.095 \pm \\
0.008\end{array}$ \\
\hline THL & $N / A \pm N / A$ & $\begin{array}{l}0.086 \pm \\
0.005\end{array}$ & $\begin{array}{l}0.195 \pm \\
0.009\end{array}$ & $\begin{array}{l}0.112 \pm \\
0.002\end{array}$ & $\begin{array}{l}0.244 \pm \\
0.009\end{array}$ & $\begin{array}{l}0.126 \pm \\
0.003\end{array}$ \\
\hline SHR & $\begin{array}{l}0.050 \pm \\
0.002\end{array}$ & $\begin{array}{l}0.029 \pm \\
0.002\end{array}$ & $\begin{array}{l}0.103 \pm \\
0.004\end{array}$ & $\begin{array}{l}0.041 \pm \\
0.002\end{array}$ & $\begin{array}{l}0.070 \pm \\
0.001\end{array}$ & $\begin{array}{l}0.042 \pm \\
0.002\end{array}$ \\
\hline SHL & $N A \pm N A$ & $\begin{array}{l}0.029 \pm \\
0.002\end{array}$ & $\begin{array}{l}0.095 \pm \\
0.008\end{array}$ & $\begin{array}{l}0.043 \pm \\
0.001\end{array}$ & $\begin{array}{l}0.066 \pm \\
0.002\end{array}$ & $\begin{array}{l}0.050 \pm \\
0.001\end{array}$ \\
\hline FTR & $\begin{array}{l}0.007 \pm \\
0.001\end{array}$ & $\begin{array}{l}0.004 \pm \\
0.002\end{array}$ & $\begin{array}{l}0.007 \pm \\
0.002\end{array}$ & $\begin{array}{l}0.004 \pm \\
0.001\end{array}$ & $\begin{array}{l}0.006 \pm \\
0.001\end{array}$ & $\begin{array}{l}0.006 \pm \\
0.001\end{array}$ \\
\hline FTL & $N A \pm N A$ & $\begin{array}{l}0.004 \pm \\
0.001\end{array}$ & $\begin{array}{l}0.006 \pm \\
0.001\end{array}$ & $\begin{array}{l}0.003 \pm \\
0.001\end{array}$ & $\begin{array}{l}0.007 \pm \\
0.001\end{array}$ & $\begin{array}{l}0.006 \pm \\
0.001\end{array}$ \\
\hline
\end{tabular}


317 Fig. 1 Total body DXA images of each Paralympic athlete in the frontal plane.

318 Fig. 2 Percent differences (\%) in the mass proportionalities of each body segment between the DXA 319 measurements and those reported by Dempster [2].

320 Fig. 3 Percent differences (\%) in the mass proportionalities of each body segment between the DXA 321 measurements and those reported by Clauser et al [1]. 